IIIIIIIIIIIIIIIIIIIIIIIIIIIII

解 説

|IIIIIIIIIIIIIIIIIIIIIIIIIII

\title{
がん一ホウ素中性子捕捉療法（BNCT）に用いる ホウ素薬剤の研究開発
}

\author{
切畑光 統* \\ 大阪府立大学 BNCT研究センター \\ （2020年7月 3 日受理）
}

\section{Research and development of boron drugs used for cancer boron neutron capture therapy (BNCT)}

\author{
Mitsunori KirIHATA \\ Research Center for BNCT, Osaka Prefecture University, 1-1 Gakuen-cho, Naka-ku, Sakai, Osaka 599-8531, Japan
}

Keywords: boron neutron capture therapy, boron drug, boron probe for PET.

\section{は じめに}

ホウ素中性子捕捉療法 (Boron Neutron Capture Therapy BNCT) は, ${ }^{10} \mathrm{~B}$-ホウ素と熱中性子の間の核変換反応（ホ ウ素中性子捕捉反応, Boron Neutron Capture Reaction BNCR）により，がん細胞を選択的損壊に導く低侵襲のが ん治療であり, その基本概念は1936年米国の物理学者 G. L. Locherにより提唱され，84年後の本年，2020年6月に保険 適応下の医療が世界に先駆けわが国で開始された。

BNCTを構成する 2 大要素技術は, 原子炉や加速器などの 中性子発生源の開発と, 腫瘍に選択集積するホウ素化合物 （ホウ素キャリヤー）であり，前者においては，近年，原子 炉に代わる病院併設が可能な小型加速器が開発・実用化さ れ，技術開発の踊り場の状態に達している。一方，ホウ素化 合物に関しては，これまで数多くの候補化合物が報告されて いるにもかかわらず，BNCTの臨床には2つのホウ素化合物

\footnotetext{
* = 599-8531大阪府堺市中区学園町 1-1 大阪府立大学研究推進機構 BNCT 研究センター

E-mail: kirihata@biochem.osakafu-u.ac.jp

(c) 日本農薬学会
}

が用いられているに過ぎず，より効果的なホウ素薬剤の開発 が強く求められている. ホウ素化合物に求められる要件は腫 瘍組織への選択的高集積であり, 最近の研究傾向は, 腫瘍に 高発現する受容体などを標的とするホウ素小分子の開発と， アルブミンや抗体等にホウ素小分子を導入したホウ素化タン

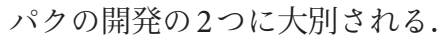

本稿では, BNCTの原理や要素技術について概説した後, 臨床実用されている2つのホウ素化合物や有望候補化合物に 焦点を当て解説する.

\section{BNCT の原理と概念一BNCR と BNCT-}

2 つの粒子 ${ }^{10} \mathrm{~B}$-ホウ素と熱中性子 $\left({ }^{1} \mathrm{n}_{\mathrm{th}}\right)$ 間の反応（BNCR） は, 図1で表される.すなわち, 2 つ粒子は遷移状態の複 合核 ([11 $\mathrm{B}]$ ) を経て, 2 項の核反応 $\left\{{ }^{10} \mathrm{~B}(\mathrm{n}, \alpha){ }^{7} \mathrm{Li}\right.$ : 上段, ${ }^{10} \mathrm{~B}(\mathrm{n}, \alpha, \gamma){ }^{7} \mathrm{Li}$ : 下段 $\}$ を惹起し， $\alpha$ 粒子 $\left({ }^{4} \mathrm{He}\right),{ }^{7} \mathrm{Li}$ 反跳核, 即発 $\gamma$ 線，熱エネルギーが発生する. G. L. Locher（米）は, J. Chadwick（英）による中性子の発見から 4 年後の 1936年に, BNCRのがん治療への応用を目指してBNCT の概念を提唱し た. ${ }^{1)}$

すなわち，がん細胞に集積させた ${ }^{10} \mathrm{~B}$-ホウ素に，低エネル ギーの熱中性子を照射してBNCRを惹起させれば，発生す 


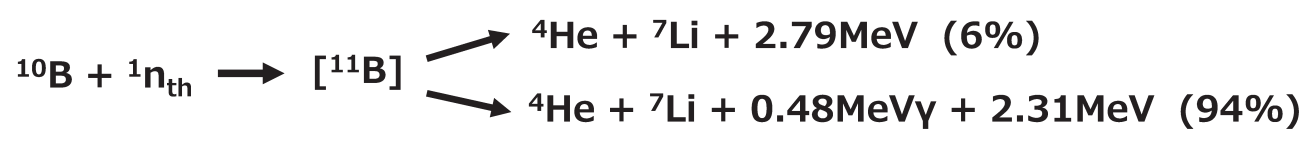

図 1. ホウ素中性子捕捉反応 (BNCR).

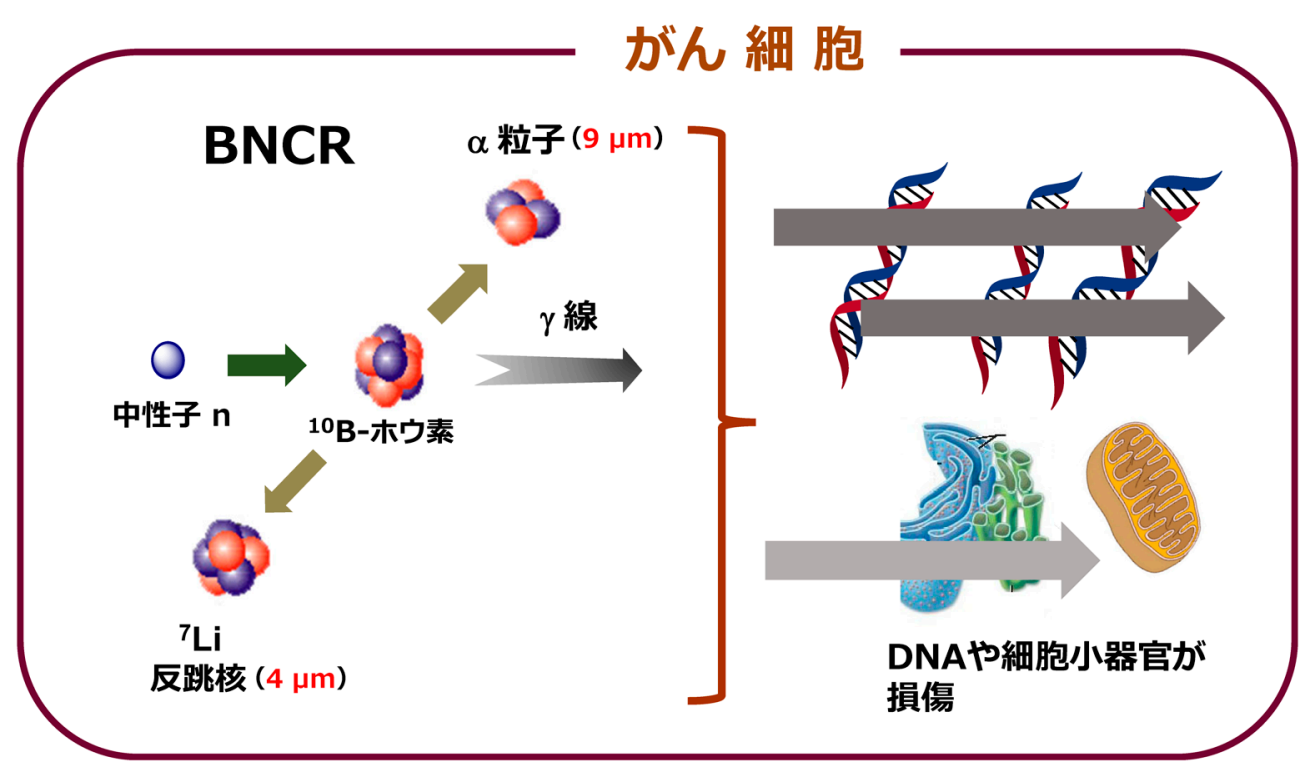

図2. ホウ素中性子捕捉療法 (BNCT) の概念.

る $\alpha$ 粒子 $\left({ }^{4} \mathrm{He}\right),{ }^{7} \mathrm{Li}$ 反跳核， $\gamma$ 線等によってがん細胞を破壊 に導き，低侵襲ながん治療に繋げることができるというコン セプトである. BNCRで生じる $\alpha$ 粒子 $\left({ }^{4} \mathrm{He}\right)$ および ${ }^{7} \mathrm{Li}$ 反跳 核の飛程は，それぞれ約 $9 \mu \mathrm{m}, 4 \mu \mathrm{m}$ と短く，がん細胞径の中 に収まり, 周囲の正常細胞や組織への損傷は少ないと考えら れ, BNCTが “がん細胞選択的治療”と呼ばれる要因となっ ている，がんをはじめ, 細胞を構成するDNAやオルガネラ に関する知見が充分でなかった時代に提唱された BNCTの 概念が，時代を経て引き継がれ，現代において医療実現され たことの意味は大きく, 図 2 には現代のBNCTの概念を示し た。

\section{2. 中性子発生源}

BNCT の中核要素である中性子は, 原子炉や加速器を発 生源として得られる。1951年に米国のブルックヘブン国 立研究所で BNCT の臨床応用が開始されて以来, 原子炉源 BNCTが世界の主流として進展してきたが, 原子炉は装置や 施設の建設・維持負担が大きく核燃料を必要とすることか ら, 原子炉に代わる病院併設型の小型加速器の開発研究が進 展し，2009年に世界初のサイクロトロン型BNCT用加速器 が現在の京都大学複合原子力科学研究所において完成した (図3). 以来, 2012年にはホウ素薬剤と組み合わせた加速器

陽子加速装置

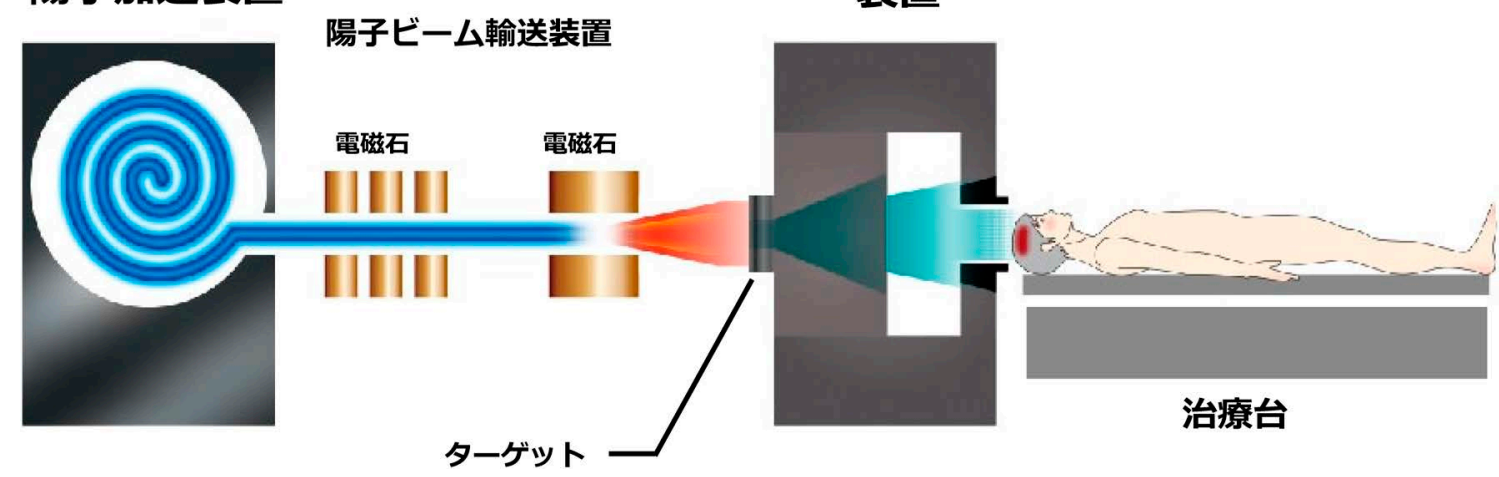

図3. BNCT用サイクロトロン型加速器の概要. 図は住友重機械工業製の加速器を示している. 


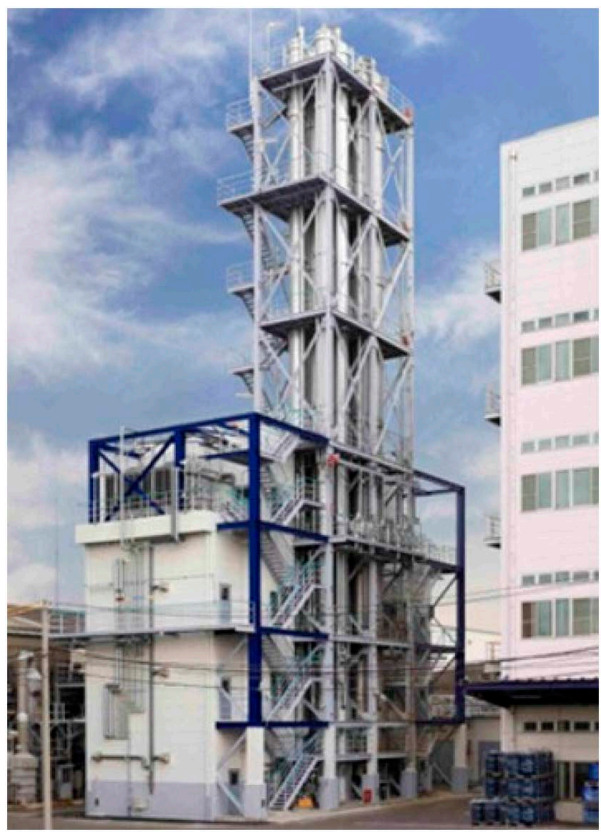

図4. ${ }^{10} \mathrm{~B}$-濃縮ホウ素製造プラント，ステラケミファ社提供.

源BNCTによる脳腫瘍，頭頸部がんの治験が世界に先駆け て国内において進行，その後承認認可を得て 2020 年 6 月よ り頭頸部がんを対象としたBNCTの実医療が実施された。

\section{3. ${ }^{10} \mathrm{~B}$-濃縮ホウ素と BNCT 用ホウ素薬剤}

\section{1. ホウ素同位体と中性子捕獲（捉）断面積}

天然ホウ素 $\left({ }^{\mathrm{n}} \mathrm{B}\right)$ には，2つの安定同位体 ${ }^{10} \mathrm{~B}$ および ${ }^{11} \mathrm{~B} か ゙$ 存在 $\left({ }^{10} \mathrm{~B} /{ }^{11} \mathrm{~B}=19.9: 20.1 \fallingdotseq 1: 4\right)$ し，中性子と反応するのは ${ }^{10} \mathrm{~B}$-ホウ素のみである。それゆえ，BNCT用ホウ素薬剂の研 究開発，医療実現には原料となる高純度 ${ }^{10} \mathrm{~B}$-濃縮ホウ素の入 手が不可欠となっている。高純度 ${ }^{10} \mathrm{~B}$-濃縮ホウ素は，世界中 で 2 社だけが大量製造しており，図 4 には大阪府泉大津市に ある製造プラントを示した。

${ }^{10} \mathrm{~B}$-ホウ素の熱中性子に対する反応性（bahn，表1）は， 水素, 酸素, 炭素, 窒素など主な生体構成元素と比べても 高く（窒素の約 2,000 倍），安全にBNCTを行いうる根拠と なっている.
表1. 主な生体元素と熱中性子間の反応.

\begin{tabular}{ccc}
\hline 元素 & 反応 & 断面積 (barn) \\
\hline${ }^{1} \mathrm{H}$ & ${ }^{1} \mathrm{H}(\mathrm{n}, \gamma){ }^{2} \mathrm{H}$ & 0.332 \\
${ }^{12} \mathrm{C}$ & ${ }^{12} \mathrm{C}(\mathrm{n}, \gamma){ }^{13} \mathrm{C}$ & 0.00386 \\
${ }^{16} \mathrm{O}$ & ${ }^{16} \mathrm{O}(\mathrm{n}, \gamma){ }^{17} \mathrm{O}$ & 0.00019 \\
${ }^{14} \mathrm{~N}$ & ${ }^{14} \mathrm{~N}(\mathrm{n}, \mathrm{p}){ }^{14} \mathrm{C}$ & 1.93 \\
${ }^{10} \mathrm{~B}$ & ${ }^{10} \mathrm{~B}(\mathrm{n}, \alpha){ }^{7} \mathrm{Li}$ & 3837 \\
\hline
\end{tabular}

barn: $10^{-24} \mathrm{~cm}^{2}$

\subsection{BNCTのホウ素化合物（ホウ素キャリヤー）に求め られる性質}

細胞選択的な低侵襲のがん治療を達成するため, BNCTの ホウ素化合物には，一般に次の(1)-60ような性質や機能が

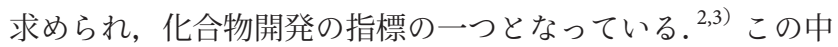
の(3)と（6)，共通認識されている具備すべき要件に，筆者ら の研究グループが実医療への実現を視野に入れて新たに付加 したものである。

(1)腫瘍細胞に選択的，かつ，多量に集積する.

・腫瘍細胞／正常細胞比（T/N比）>3

・20-40ppm の腫瘍内ホウ素濃度

(2)血中投与するため低毒性で高い安全性が保障・確保され る.

(3)体内動態や濃度がPET（陽電子断層撮影法）等で非侵襲的 に計測評価できる。“theranostics”な特性を有することが 望ましい.

(4)腫瘍組織に一定時間滞留し, 治療終了後は速やかに排出さ れる。

(5)1分子あたりのホウ素占有率が高く中性領域下で水溶性で ある。

(6)ホウ素送達のキャリヤー分子としての機能を優先して有

し，薬理活性をもつことは必ずしも求められない.

これらの中で，BNCTに特有で重要な性質は(1)であり， BNCT の成否を左右する根幹でもある。それ故，BNCT用ホ ウ素化合物の研究開発では, (1)の条件克服を第一目標として 展開される事例が多い。

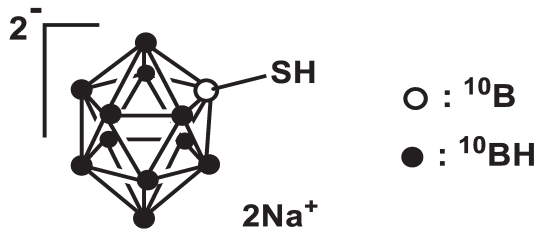

Disodium closo-mercaptoundecahydrododecaborate BSH

図 5. BNCTの臨床に実用されているホウ素化合物. 
表2. BNCTにおけるBPA と BSH の特性比較.

\begin{tabular}{|c|c|c|}
\hline & BPA & $\mathrm{BSH}$ \\
\hline >属性 & ・アミノ酸 (AA), ボロン酸 & ・籠型ホウ素クラスター \\
\hline$>$ 物理化学的特性 & $\begin{array}{l}\text { • 低水溶性 } \\
\text { • B密度 : } 4.8 \% \mathrm{~W} / \mathrm{MW} \\
\text { • 多価アルコールと複合体を形成 }\end{array}$ & $\begin{array}{l}\text { ・水溶性, } 2 \text { 価無機イオン } \\
\text { • B密度 }: 73.1 \% \mathrm{~W} / \mathrm{MW}(-2 \mathrm{Na})\end{array}$ \\
\hline >生物特性 & $\begin{array}{l}\text { ・低毒性 } \\
\text { ・細胞質，核内に分布 } \\
\text { ・タンパク合成に資化されない }\end{array}$ & $\begin{array}{l}\text { ・低毒性 } \\
\text { ・細胞内に分布, ミクロ分布? }\end{array}$ \\
\hline >取り込み機構 & $\begin{array}{l}\text { アミノ酸トランスポーターLAT } \\
\text { ・腫瘍細胞 : LAT1, ATB }{ }^{0,+} \\
\text { ・正常細胞 : LAT2 }\end{array}$ & $\begin{array}{l}\text { ・取り込み機構? } \\
\text { 脳腫瘍の血液脳関門を通過 }\end{array}$ \\
\hline >適応がん腫 & $\begin{array}{l}\text { • 悪性黒色腫 } \\
\text { •脳腫瘍 } \\
\text { •頭頸部がん etc.(BSH との併用) }\end{array}$ & $\begin{array}{l}\text { - 脳腫瘍 etc. } \\
\quad(B P A \text { との併用) }\end{array}$ \\
\hline > PET プローブ & $\cdot\left[{ }^{18} \mathrm{~F}\right]-\mathrm{FBPA}$ & •未開発 \\
\hline
\end{tabular}

\subsection{BNCTの臨床に用いられているホウ素化合物}

現在，BNCTの臨床には2つのホウ素化合物（図5）が用 いられている。 L-BPA（以下，BPA）は1987年三嶋らにより メラノーマ (悪性黒色腫) のBNCTに用いられ, ${ }^{4}$ ) その後, 脳腫瘍や頭頸部がん等を対象としたBNCTの臨床研究に広 く用いられている. 本年6月に始ったBNCTの実医療に用 いられたホウ素薬剤“ボロファラン $\left({ }^{10} \mathrm{~B}\right)$ ” (ステボロニン ${ }^{\circledR}$ ) は，BPAを有効成分として製剤化されたものである．20面 体の籠型ホウ素クラスターである BSH は，畠中らにより悪 性脳腫瘍のBNCT用ホウ素薬剤として最初に用いられた。 BSH は，また後年, BPA と併用して悪性神経膠腫のBNCT にも用いられている. ${ }^{6}$ 16面体のホウ素クラスターDecaborate（図 10）がアルゼンチンにおいて臨床に用いられたと聞 くが，その詳細は確認できていない.

\subsection{BPA と BSHの化学・生物学的特性と BNCT}

臨床に実用されているBPA と BSHの諸性質, 対象とする がん腫などを比較して表2に示した．BPAは，悪性黒色腫 (メラノーマ）のBNCTに用いられ，高い治療効果が得られ
たことから, メラニン生合成の前駆体であるフェニルアラニ ンの mimicとして取り込まれると考えられていたが, その 後, メラニン生産能が低く代謝が克進している他のがん腫に おいても高いBPA集積が報告され, 別の取り込み機構の存 在が示唆された. ${ }^{7}$ 嵩高い中性アミノ酸の輸送に関わるLAT トランスポーターが1998年に金井により発見され, ${ }^{8)}$ LAT1 は腫瘍細胞において，またサブタイプのLAT2 は正常細胞に おいて発現し, BPAはこれらLATトランスポーターを介し て細胞内に輸送されることが明らかとなった. ${ }^{9)}$

LAT1は多くのがん腫において高発現し, その発現頻度は 正常細胞のLAT2のそれよりも高く, BPAの腫瘍／正常細胞 選択性比（T/N比）は，これらの発現頻度に依存している と考えられている. BPAは, もう一つのトランスポーター $\mathrm{ATB}^{0,+}$ によっても細胞内に運ばれるが，LAT1がほとんどの がん腫において高発現しているのに対して, $\mathrm{ATB}^{0,+}$ を発現 するがん腫は限られている，BPAの動態や腫瘍による取り 込み機構が明らかにされているのに対して, BSHの体内動 態については, 現在においてもなお不明な点が多い（表2).

\section{C6 (ラットグリオーマ) 細胞}

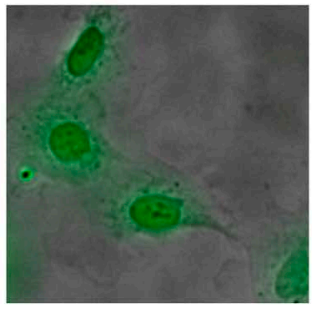

2B10による免疫染色

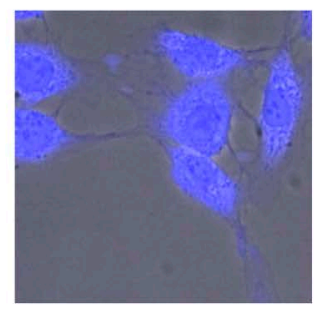

DAHMIによる蛍光染色

図6. $2 \mathrm{~B} 10$ と DAHMIによるミクロ分布解析. 
<smiles>N[C@@H](Cc1ccc(B(O)O)cc1Br)C(=O)O</smiles>

[18F]FBPA

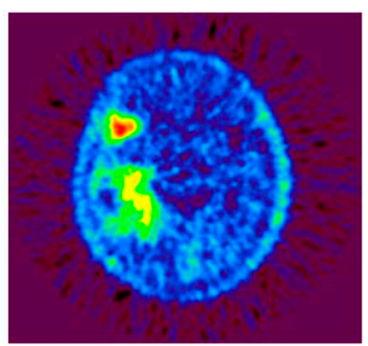

図 7. ${ }^{18} \mathrm{FBPA}$ と脳腫瘍の PET画像. PET 画像提供：大阪医科大学 宮武伸一教授

\subsection{BPAの細胞内ミクロ分布解析}

BNCTでは，腫瘍細胞に取り込まれたホウ素化合物が核内 移行し，DNA近傍に局在した場合に高い治療効果が発揮さ れると考えられ，マイクロドジメトリーとの関連から，ホウ 素化合物の細胞内ミクロ分布解析が重要になっている。わ れわれは, BPAの組織動態や細胞内ミクロ分布を明らかに するため, 2つのツール分子, 抗BPAモノクローナル抗体 （2B10）と蛍光センサーDAHMI を開発，免疫染色や蛍光染 色によるBPAの動態解析に活用している．2B10による免疫 細胞化学染色により BPA は細胞質や核内に広く分布するこ とか明らかになった（図6）.

また，低毒性で細胞膜浸透性の高いDAHMIによるライブ セルイメージングにより，BPAの細胞内移行を経時的に画

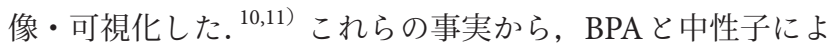
る BNCRは腫瘍細胞の核や細胞質内で惹起され，発生した $\alpha$ 粒子, ${ }^{7} \mathrm{Li}$ 反跳核, 即発 $\gamma$ 線などが近傍の核内 DNA やオル ガネラを強く損傷してがん細胞を破壊に導くものと考えられ る.

\subsection{PETによる BPA 動態解析}

石渡らは, BPAのオルソ位水素をポジトロン（陽電子） 発生元素である ${ }^{18} \mathrm{~F}$-フッ素（半減期：109.8分）に置換し た $\left[{ }^{18} \mathrm{~F}\right]-\mathrm{FBPA}$ (以下 ${ }^{18} \mathrm{FBPA}$, 図 7) を開発し, ${ }^{18} \mathrm{FBPA}$ プローブ分子とする PET（陽電子断層撮影法）測定により， BPA動態が追跡できることを報告した. ${ }^{12)}$

渡邊らは, 物理化学的性質が異なる $\mathrm{BPA} と{ }^{18} \mathrm{FBPA}$ 動態の 同等性の比較検証を目的に，半減期のない ${ }^{19} \mathrm{FBPA} と \mathrm{BPA}$ 用いた実験系を構築して評価した。等モル数（BNCTと同じ 薬物量）の ${ }^{19} \mathrm{FBPA}$ と BPAをモデルマウスに投与して血液,
器官, 臓器等における両化合物の集積量を解析し, 両化合物

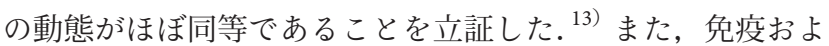
び蛍光染色によるミクロ分布解析から, 両化合物の細胞内動 態の同等性を明らかにした。

BPA BNCTの臨床においては, ${ }^{18}$ FBPA PET測定は不可 欠な検査項目と位置づけられ, 画像データは治療計画作成 の基となっている.これまで， ${ }^{18} \mathrm{FBPA}{ }^{18} \mathrm{~F}_{2}$ より調製した $\left[{ }^{18} \mathrm{~F}\right]-\mathrm{AcOF}$ により BPAをフッ素化する所謂“Fプラス法”に より合成されてきたが, ${ }^{12)}$ 放射化收率が低く, 合成方法に改 善の余地があった。われわれは従来の“Fプラス法”に代わり 前駆体に $\left[{ }^{18} \mathrm{~F}\right]-\mathrm{HF}$ を反応させる “Fマイナス法”を考案, 大 量合成が可能な ${ }^{18} \mathrm{FBPA}$ の新規合成法を開発した（図 8). ${ }^{14)}$

\section{BNCT 用新規ホウ素化合物 （ホウ素キャリヤー）の開発研究}

BNCT 用ホウ素化合物は, 一般に腫瘍親和性分子 ${ }^{10} \mathrm{~B}-$ ホウ素分子がリンカーにより結ばれた構造を取っている (図9).

腫瘍親和性分子には，腫瘍細胞表層に高発現する受容体， トランスポーター, チャンネル, 血管や膜構造等を標的とす るアミノ酸, ペプチド, 生理活性物質, 抗体などが, また, ${ }^{10} \mathrm{~B}$-ホウ素分子部にはボロン酸やボリン酸, ホウ素クラス ター類が用いられている. ${ }^{15)}$ 最近では, 腫瘍親和性分子部が 高分子化し，これに伴うホウ素密度の低下を妨げるために複 数のホウ素クラスターを多用する傾向が見受けられる。この 背景には, 近年の医薬品開発ではがん抗体などの分子標的薬 研究が周辺領域に拡大, 波及し, BNCTのホウ素化合物の研 究開発もその影響を受けていると考えられる.

3 中心 2 電子結合から成るホウ素クラスターには，水溶性
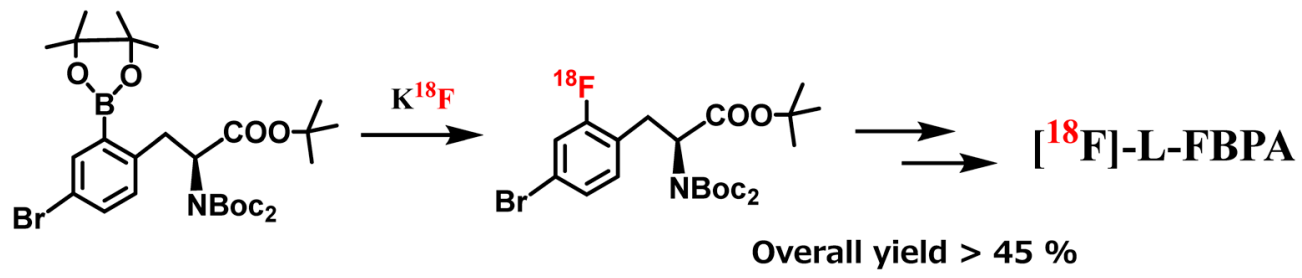

図 8. “Fマイナス法”による ${ }^{18} \mathrm{FBPA}$ 合成. 


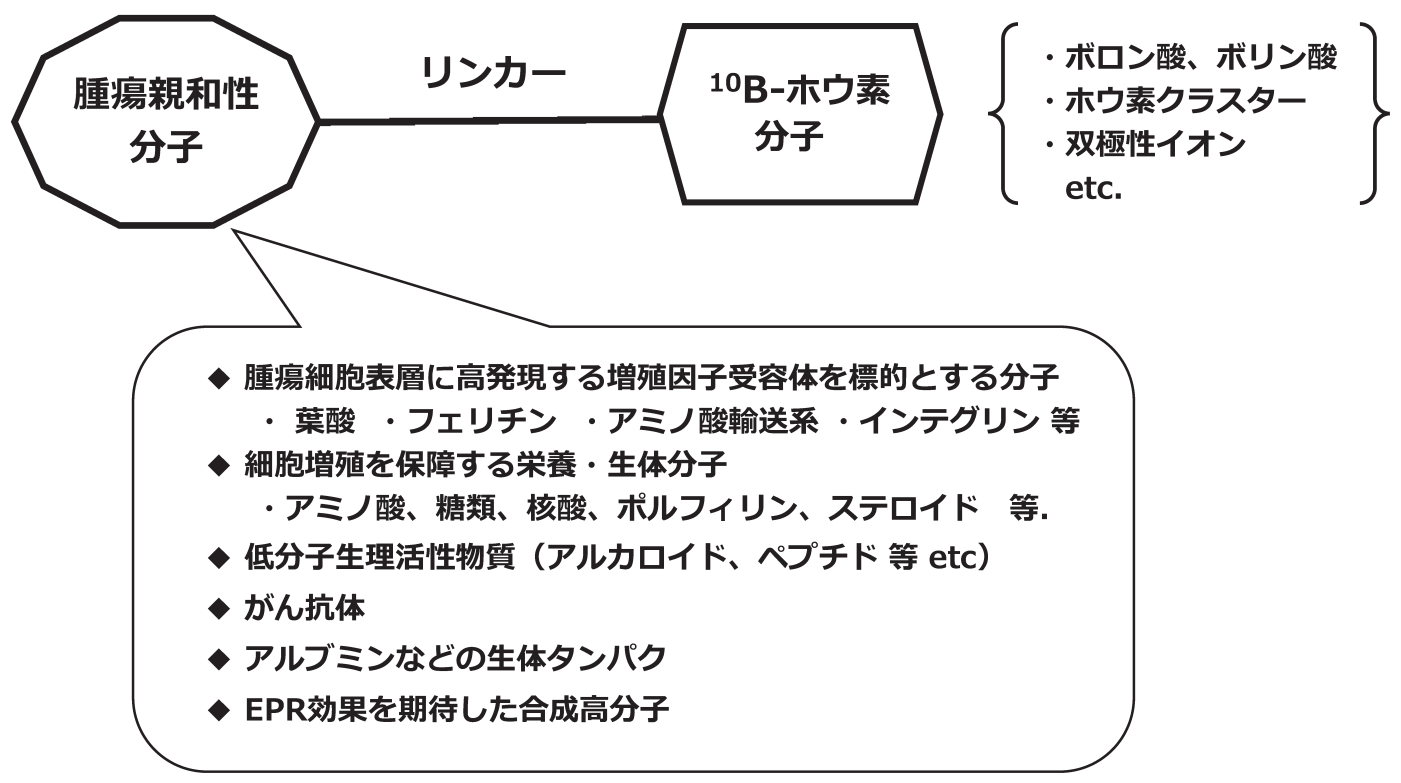

図9. BNCT用ホウ素化合物の模式構造.

の closo-Dodecaborate やDecaborate と疎水性のo-Carborane があり（図 10）, 有機溶媒に可溶な $o$-Carborane類は炭素炭素間結合の構築による誘導体化が容易で, 医薬の分子設計 ではファマコホアの活性を増強させる疎水性補欠分子族とし て活用されている. $\mathrm{BSH}, \mathrm{BOH}, \mathrm{BNH}_{2}$ などの水溶性のclosoDodecaborate類は低毒性で，それぞれ-S-, -O-, -N-を介した 誘導体化, 有機分子化が可能であるが, 陰イオン性のホウ素 クラスター部の影響を受け, 特殊な反応条件が必要になる場 合が多く, 構造確認や純度測定にも蓄積したノウハウが必要 となる，ホウ素密度の高いクラスター類は, 高い腫瘍内ホウ 素濃度の達成が求められる BNCT分野だけにとどまらず，今 後, 医薬や機能性分子などへの応用が拡大すると思われる.

BPAを有効成分とする“ボロファラン $\left({ }^{10} \mathrm{~B}\right) ”$ (ステボロニ
ン $\left.{ }^{\circledR}\right)$ が最初のBNCT薬剤として承認認可されたことは，今 後のホウ素化合物開発に大きな影響を与えると思われる. 何 よりも，BPAを基準として，これを凌駕する化合物開発が求 められる. 安全性は無論, 腫瘍集積性や選択性, 特定がん 腫への適合性, アドメ過程, 経済性などの諸要素において, BPAを超える化合物開発を視野に入れなければならない. 研究論文の審査等においても, BPAをポジティブコントロー ルとした比較試験の結果が求められていくであろう.

このような背景から, 本稿では, 分子量を基にこれまで報 告されてきた多くの候補化合物を, 低分子, 中分子, 高分子 およびDDSの3つに分け, BPAを基準とした新たな視点か ら再評価して，それぞれの分野の有望な候補化合物を選び, 次に紹介・解説することとした.

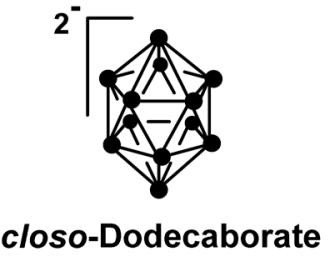

$\left[\mathrm{B}_{12} \mathrm{H}_{12}\right]^{2-}$
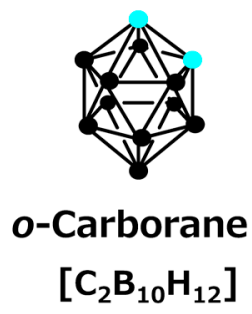
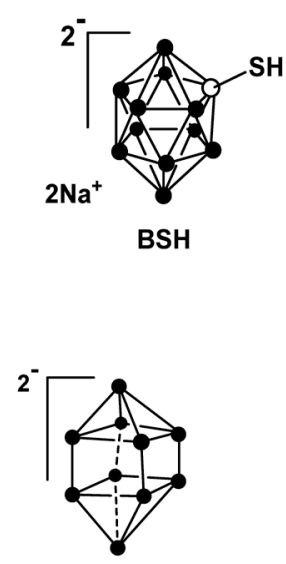

Decaborate

$\left[\mathrm{B}_{10} \mathrm{H}_{10}\right]^{2-}$

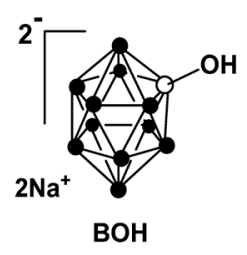

$\mathrm{Na}^{+}$

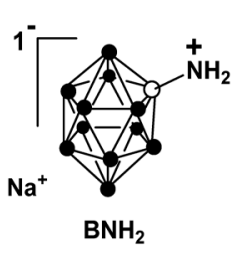

\section{3 中心2電子結合}

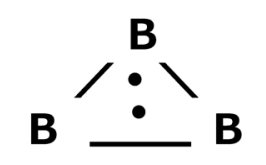

3つのBが 2つの 電子を共有

図 10. 籠型ホウクラスターと 3 中心 2 電子結合. 


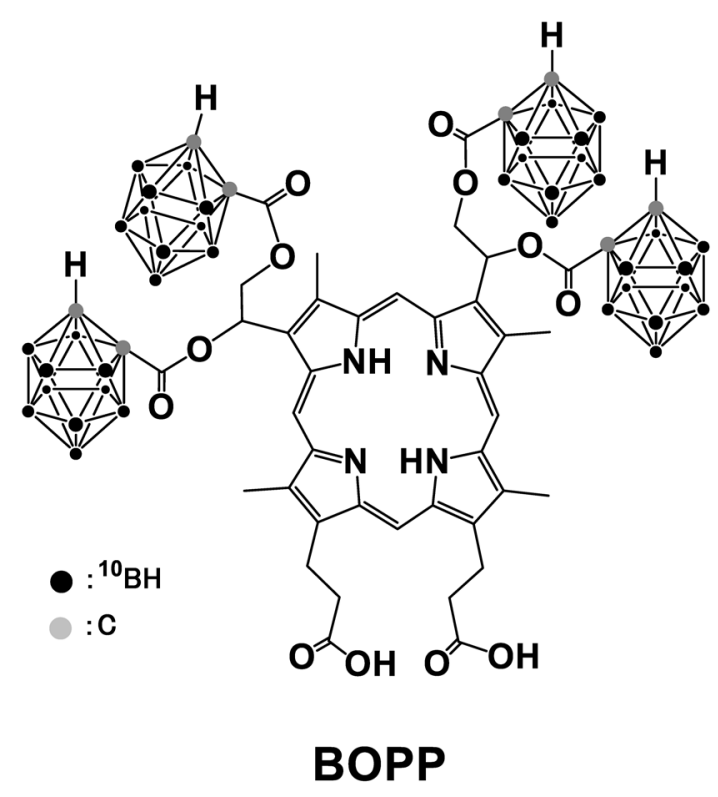

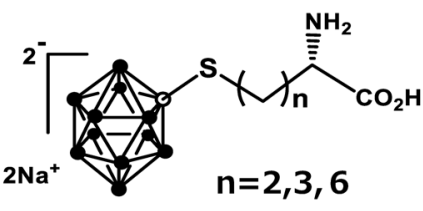

BSH-AA
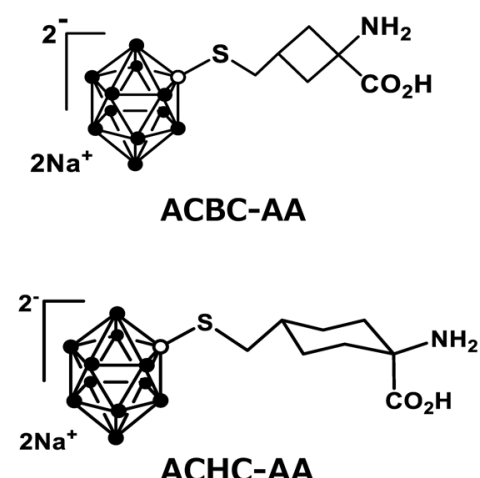

図11. ホウ素ポルフィリンとホウ素アミノ酸.

\section{1. 低分子ホウ素化合物}

4.1.1. ホウ素化ポルフィリン

ポルフィリン類の中には, 共通する光増感作用の他に, 腫 瘍に選択集積性を有する化合物が知られている。ポルフィリ ン骨格にホウ素クラスターを導入したホウ素化ポルフィリ ンは, BNCT と PDT (光線力学的療法) との併用が期待で き，蛍光イメージングなどによる動態の可視化も容易で，木 ウ素キャリヤーに求められるセラノスティックな特徵を備 えていることから，多くの類縁体が報告されてきた，Karl らはポルフィリン骨格に4個のo-Carborane（40個のホウ素 原子）を導入したBOPPを開発した（図11). ${ }^{16)}$ BOPP は䜣 vitro, in vivo試験で高い腫瘍集積性を示し, 非臨床試験の 結果も良好なことから期待が高まったが，PhaseI試験にお いてBOPPあるいはその代謝物による血小板（thrombocytopenia）減少か観察され，開発ラインから脱落した，先に述心゙ たように，ポルフィリン骨格はホウ素キャリヤーに求められ る基盤要件を備えており, クロリン, フタロシアニン，ポル フィラジンなどにホウ素クラスターを導入した誘導体の合成 が進められている。
4.1.2. ホウ素アミノ酸

BPAに代表されるように， $\alpha$-アミノ酸をホウ素化した $\alpha$ ホウ素アミノ酸は, 通常アミノ酸の mimicとして細胞増殖 の盛んな腫瘍細胞に取り込まれる可能性が高く, 服部らは BSHのメルカプト基を段階的にアルキル化する反応を基盤 に, $\alpha$-アミノ酸の側鎖にBSH を導入したBSH-AA, $\alpha, \alpha$-シ クロアルキルアミノ酸 ACBC-AA, ACHC-AAの合成とホウ 素キャリヤーとしての生物活性を報告している (図 11). ${ }^{17,18)}$ ホウ素アミノ酸は水溶性, 低細胞毒性であり, ミクロ分布解 析により腫瘍細胞の核周辺に局在集積することが明らかと なった。また, 中性子照射実験から, L-BPA と同程度のホウ 素を送達することで高いBNCTによる殺細胞効果を示すこ とを明らかにしている.

4.1.3. 低分子ホウ素ペプチド

オリゴペプチドトランスポーター（PEP）には，2つのト ランスポーターPEP1とPEP2があり, PEP1はPEP2に比べ て多くの腫瘍細胞で高発現している. 金井らは, BPA-Tyr およびTyr-BPA の 2 種類の BPA ジペプチドを用いてPEP1お よびPEP2による腫瘍細胞への取り込みをin vitroおよびin vivoで解析, AsPC-1（すい臓がん）細胞では, これらのジ
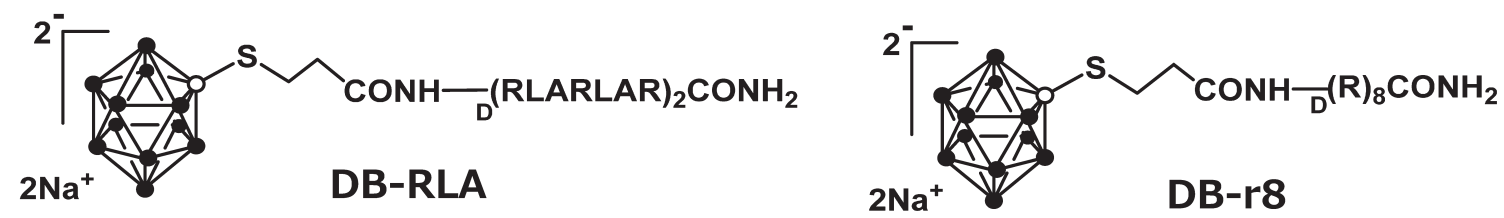

図 12. ミトコンドリアを標的とする膜透過性ホウ素ペプチド. 

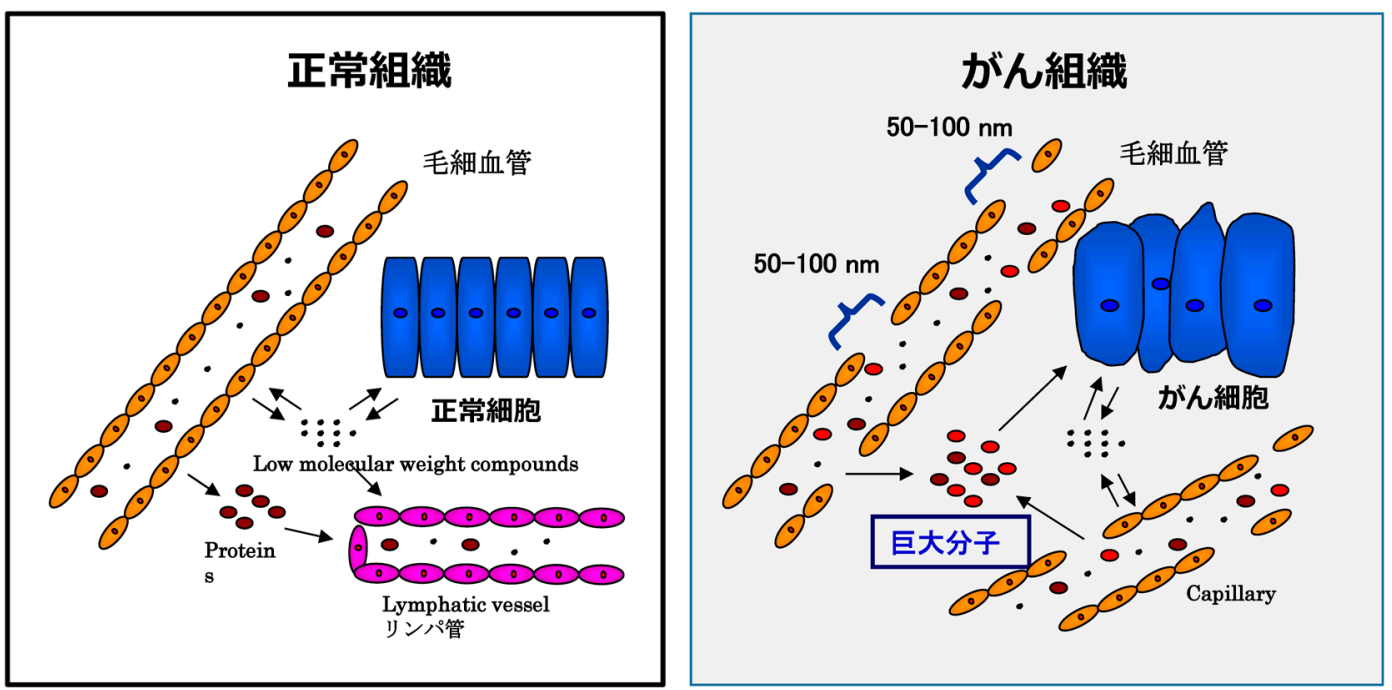

図 13. EPR (enhanced permeability and retention effect) 効果.

ペプチドはPEP1により輸送されることを明らかにした。ま た，すい臓がん細胞を異種移植したマウスに両ジペプチド を静注したところ，BPAを $\mathrm{N}$ 末端とする BPA-TyrがPEP1 を 介して腫瘍に多量集積したことを確認，これらの事実から， BPAオリゴペプチドがホウ素キャリヤーとして有望である と報告している. ${ }^{19)}$

\section{2. 中分子ホウ素化合物}

特定の細胞内オルガネラを標的としたホウ素キャリヤーに 関する研究報告は少なく，次に述べるミトコンドリアを標的 とした報告は最初の例といえる。中瀬らは最近，ミトコンド リアに集積性を示す膜透過性ペプチドRLAおよび，サイト ゾルへの集積性を示す高い膜透過性ペプチド R8のN末側に リンカーを介してBSHを導入したDB-RLAおよびDB-R8の 2つのホウ素化ペプチドを合成, 細胞内取り込みと局在につ いて検討した. DB-RLAは細胞膜を通過後にミトコンドリ アに著しく集積することが確認された。一方，DB-R8はミ トコンドリアを避けてサイトゾルへの集積が観察された。ま た，両者の細胞内のホウ素取込み量は, BSH-AA（図 12）と
比較して約 10 倍上昇した.さらにDB-RLAは暴露後30分 でミトコンドリアに集積し，24時間経過後もミトコンドリ アに局在維持されることが確認された。一方，DB-R8は， DB-RLAの場合と異なりサイトゾルに長時間保持されない ことが観察され, ${ }^{20)}$ in vitro 中性子照射実験では, DB-RLA は 腫瘍細胞に対して高い殺細胞効果を示した。

腫瘍細胞表層に高発現する受容体タンパクに対して高い親 和性を持つペプチドをo-Carboraneやcloso-Dodecaborateで 化学修飾したホウ素ペプチドは, BNCTのホウ素キャリヤー として有望ではないかと注目されている. 永澤らは, 細胞 接着やがん転移に関係し, 腫瘍細胞表層に高発現するイン テグリン $\alpha_{\mathrm{v}} \beta_{3}$ を標的として, 環状RDGペプチド（Arg-GlyAsp）にリンカーを介して BSHやo-Carboraneを 1-2 分子導 入したホウ素ペプチドを分子設計・合成している．これらの ペプチドは $\alpha_{\mathrm{v}} \beta_{3}$ への高い親和性を示し, 中でも2分子の環 状RDGペプチドにo-カルボランを導入したホウ素ペプチド は, 腫瘍モデルマウスによるin vivo実験で高い腫瘍選択性 と集積性を示す興味深い結果が報告されている. ${ }^{21)}$

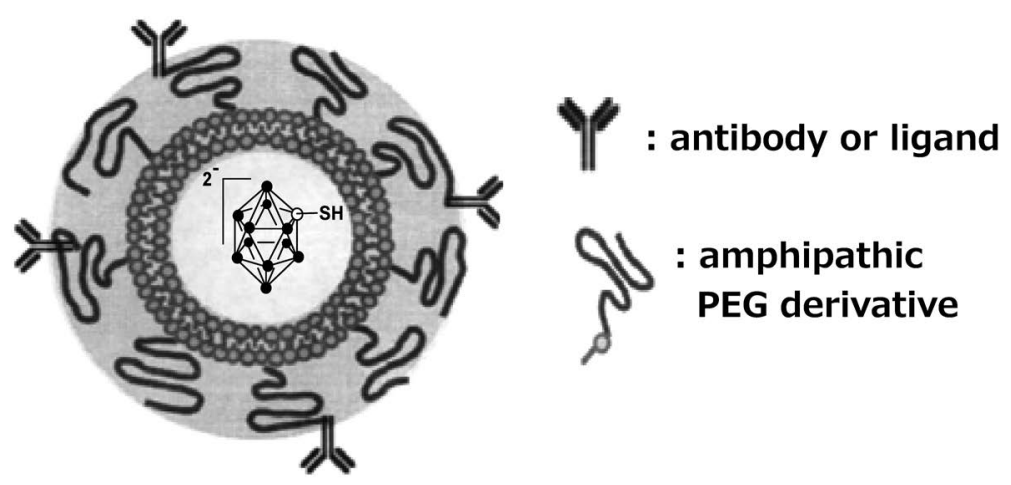

図 14. トランスフェリン受容体を標的とする PEGリポソーム. 

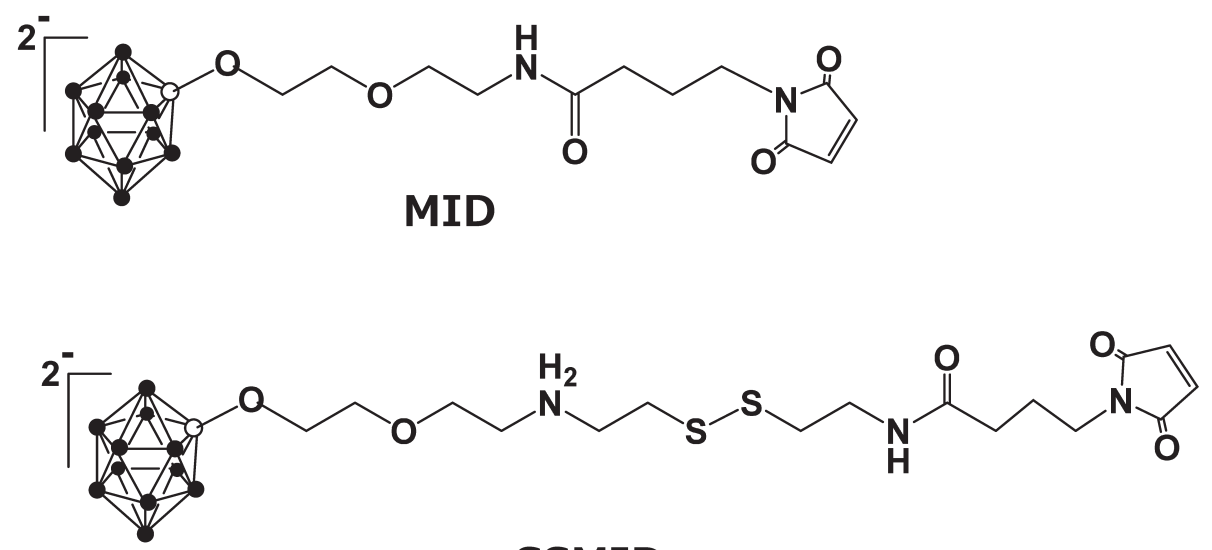

SSMID

図 15. closo-Dodecaborate含有アルブミン修飾剤.

\section{3. 高分子ホウ素化合物・DDS}

腫瘍組織では, 正常組織に比べ血管透過性が著しく克進 しているため，高分子や微粒子が血管より流出しやすく，ま た, リンパ系が発達していないため, 腫瘍組織に到達した物 質は蓄積することが知られており，このような特性を EPR 効果（enhanced permeability and retention effect）と呼ばれ ている. 腫瘍組織の毛細血管の間隙は 50-100 nm程度と大 きく，正常組織の毛細血管では通過できない巨大分子が，腫 瘍組織では通過することができるため, 分子の大きさに基 づく選択的送達が期待できる（図 13）.EPR効果はリポソー ムや包接分子による腫瘍を標的とするDDS等の理論的根拠 となってきた．ホウ素キャリヤーの開発においても，多数の ホウ素クラスターを導入して, ホウ素密度を向上させたポリ ペプチド，タンパク質，デンドリマーなどが報告されている が，臨床には至っていない。

丸山らは，鉄イオンの細胞送達を担っているトランス フェリン（TF）受容体が，正常細胞に比べて腫瘍細胞で高 発現していることに着目，TFに親和性を示す PEGリポソー ム（TF-PEGリポソーム，図14）を開発した. TF-PEGリポ ソームは腫瘍内で高いホウ素濃度レベルを達成, 注入後, 少 なくとも 72 時間は腫瘍 $1 \mathrm{~g}$ あたり $30 \mu \mathrm{g}$ を超えるホウ素濃度 が維持された. 22

中村らは高分子タンパクにcloso-Dodecaborateを導入する ためのホウ素修飾剤MIDを開発した（図 15)，MIDを牛血 清アルブミン（ABS）に作用させたところ，Cys34の-SHだ けでなく，3つのリジン残基Lys221，Lys413 およびLys431の アミノ基がマレイルイミドの二重結合との間で Michael付加 反応を起こしていることを見出した．さらに，アルブミン結 合部位の同定のためにジスルフィド結合を有するSSMIDを 開発している.-SH とマレイルイミド間の付加反応を利用し たタンパク質の化学修飾や架橋は一般的な手法として定着し ているが，リジン残基のアミノ基との反応例は少ない．アル ブミンに特有の反応であるかどうかの検証は必要であるが,
疎水ポケット近傍のリジン残基や抗体タンパク等への応用が 期待されるところである。 また，closo-Dodecaborate修飾さ れたホウ素化アルブミンの BNCTへの応用が期待される. 23 )

\section{おわりに}

BPAを有効成分とするホウ素薬剤の承認認可を受けて, 頭頸部がんを対象とした BNCT の実臨床が本年6月に開始さ れた。頭頸部がんに次いで, 悪性脳腫瘍, 悪性黒色腫, 血管 肉腫など進行中の治験結果が待たれるところである，通常の 医薬とは異なり, 腫瘍組織への選択的高集積がホウ素化合物 に求められる要件であり, 本稿で取り上げた有望な候補化合 物のさらなる進展が期待される。また， BNCTとは直接に関 係しないが, 多発性骨髄腫治療薬のテルアミゾブや抗真菌薬 のタバボロールなど, ボロン酸医薬の作用機序や開発の過程 等が簡潔に解説され，医薬創製のパーツとしてのボロン酸の 有用性や可能性について述心゙られている記事が, 最近, 発表 されたので紹介しておきたい. ${ }^{24)}$

\section{引用文 献}

1) G. L. Locher: Am. J. Roentgenol. Radium. Ther. 36, 1 (1936).

2) M. F. Hawthorne: Angew. Chem. Int. Ed. Engl. 32, 950-984 (1993).

3) A. H. Soloway, W. Tjarks, B. A. Barnum, F.-G. Rong, R. Barth, I. M. Codogni and J. G. Wilson: Chem. Rev. 98, 1515-1562 (1998).

4) Y. Mishima, C. Honda, M. Ichihashi, H. Obara, J. Hiratsuka, H. Fukuda, H. Karashima, T. Kobayashi, K. Kanda and K. Yoshino: Lancet 334, 388-389 (1989).

5) H. Hatanaka: "Preface," ed. by H. Hatanaka, Boron Neutron Capture Therapy for Tumors Nishimura Co., Ltd. Niigata.

6) S. Kawabata, S.-I. Miyatake, T. Kuroiwa, K. Yokoyama, A. Doi, K. Iida, K. Miyata, N. Nonoguchi, H. Michiue, M. Takahashi, T. Inomata, M. Kirihata, Y. Sakurai, A. Maruhashi, H. Kumada and K. Ono: J. Radiat. Res. (Tokyo) 50, 51-60 (2009).

7) J. L. Mallesch, D. E. Moore, B. J. Allen, W. H. McCarthy, R. Jones and W. A. Stening: Int. J. Radiat. Oncol. Biol. Phys. 28, 1183-1188 
(1994).

8) Y. Kanai, H. Segawa, K. Miyamato, H. Uchino, E. Takeda and H. Endou: J. Biochem. Chem. 273, 23629-23632 (1998).

9) A. Wittig, W. A. Sauerwein, J. A. Coderre and J. A. Coderre: Radiat. Res. 153, 173-180 (2000).

10) Y. Hattori, M. Ishimura, Y. Ohta, H. Takenaka and M. Kirihata: SENSORS 1, 1394-1397 (2016).

11) Y. Hattori, M. Ishimura, Y. Ohta, H. Takenaka, T. Watanabe, H. Tanaka, K. Ono and M. Kirihata: Org. Biomol. Chem. 3, 69276930 (2015).

12) K. Ishiwata, T. Ido, A. A. Mejia, M. Ichihashi and Y. Mishima: Appl. Radiat. Isot. 42, 325-328 (1991).

13) T. Watanabe, Y. Hattori, Y. Ohta, M. Ishimura, Y. Nakagawa, Y. Sanada, H. Tanaka, S. Fukutani, S.-I. Masunaga, M. Hiraoka, K. Ono, M. Suzuki and M. Kirihata: BMC Cancer 16, 859-859 (2016).

14）竹中宏誌・大田洋一郎・上原幸樹ら（ステラファーマ株式会 社) ・切畑光統 (大阪府立大学) : PCT/JP2015/052303.

15) H. Nakamura and M. Kirihata: "Boron Compounds: New Candidates for Boron Carriers in BNCT, ed. by W.A.G. Sauerwein, A. Wittig, R. Moss, Y. Nakagawa, "Neutron Capture Therapy" Springer, Heidelberg, pp. 99-116, 2012.

16) S. B. Karl and M. S. Koo: J. Chem. Soc. Chem. Commun., 17691771 (1990).

17) Y. Hattori, S. Kusaka, M. Mukumoto, K. Uehara, T. Asano, M. Suzuki, S. Masunaga, K. Ono, S. Tanimori and M. Kirihata: J. Med. Chem. 55, 6980-6984 (2012).

18) Y. Hattori, S. Kusaka, M. Mukumoto, M. Ishimura, Y. Ohta, K.
Uehara, T. Asano, M. Suzuki, S. Masunaga, K. Ono, S. Tanimori and M. Kirihata: Amino Acids 46, 2715-2720 (2014).

19) J. Miyabe, R. Ohgaki, K. Saito, L. Wei, L. Quan, C. Jin, X. Liu, S. Okuda, S. Nagamori, H. Ohki, K. Yoshino, H. Inohara and Y. Kanai: J. Pharmacol. Sci. 139, 215-222 (2019).

20) I. Nakase, M. Katayama, Y. Hattori, M. Ishimura, S. Inaura, D. Fujiwara, T. Takatani-Nakase, I. Fujii, S. Futaki and M. Kirihata: Chem. Commun. (Camb.) 55, 13955-13958 (2019).

21) S. Kimura, S. Masunaga, T. Harada, Y. Kawamura, S. Ueda, K. Okuda and H. Nagasawa: Bioorg. Med. Chem. 19, 1721-1728 (2011).

22) K. Maruyama, O. Ishida, S. Kasaoka, T. Takizawa, N. Utoguchi, A. Shinohara, M. Chiba, H. Kobayashi, M. Eriguchi and H. Yanagie: J. Control. Release 98, 195-207 (2004).

23) S. Ishi, S. Sato, H. Asami, T. Hasegawa, J. Kono and H. Nakamura: Organic Mol. Chem. 17, 5496-5499 (2019).

24) 百瀬 功・渡邊 巧：ファルマシア 56, 416-420 (2020).

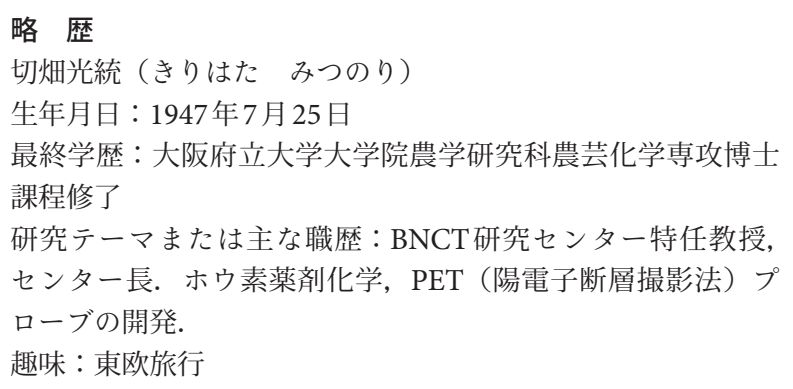

